\title{
Betamethasone inhibits tumor development, microvessel density and prolongs survival in mice with a multiresistant adenocarcinoma TA3
}

\author{
Osvaldo Garrido', René Letelier ${ }^{1}$, Carlos Rosas ${ }^{1}$, Marcela Fuenzalida ${ }^{1}$, Arturo Ferreira ${ }^{2}$ and David Lemus ${ }^{1}$ \\ ${ }^{1}$ Programa Disciplinario de Anatomía y Biología del Desarrollo, ICBM, Facultad de Medicina, Universidad de Chile, Independencia 1027 Santiago, Chile. \\ 2 Programa Disciplinario de Inmunología, ICBM, Facultad de Medicina, Universidad de Chile, Independencia 1027 Santiago, Chile.
}

\begin{abstract}
Tumor resistance to traditional cancer treatments poses an important challenge to modern science. Thus, angiogenesis inhibition is an important emerging cancer treatment. Many drugs are tested and corticosteroids have shown interesting results. Herein we investigate the effect on microvessel density, survival time and tumoral volume of mice with TA3-MTX-R tumors. Twenty six mice were inoculated with $1 \times 10^{6}$ tumor cells, 4-5 days after injection, six mice were injected with PBS (group A) and twenty mice were treated with $\beta$-met (group B). All animals from Group A died on day 22. Group B was divided into B1 (treated discontinued) and B2 (treated daily) and observed until day 88. All mice were processed for histo-immunohistochemical analysis and the blood vessels were counted. A decrease in microvessel density and tumoral volume and longer survival times were observed in the treated group. We propose that the antiangiogenic $\beta$-met effect explains, at least partially, its tumor inhibitory properties. As an important perspective, we will experimentally combine these strategies with those recently described by us with regard to the important antiangiogenic-antitumor effects of Trypanosoma cruzi calreticulin. Since the molecular targets of these strategies are most likely different, additive or synergic effects are envisaged.
\end{abstract}

Key terms: angiogenesis, betamethasone treatment, metastasis.

\section{INTRODUCTION}

Angiogenesis, the development of new blood vessels, is a fundamental physiological process that promotes embryonic development, tissue repair and fertility, although it also promotes chronic inflammation, tumor growth and tumor metastasis (Carmeliet, 2005; Aranda \& Owen, 2009). It is now widely accepted that when the effect of proangiogenic and antiangiogenic molecules is tipped in favor of the former, the process is activated (Malonne et al., 1999; Hanahan and Weinberg, 2000; Bouck et al., 1996, Pike Se et al., 1999, Ferreira et al., 2005) New blood vessels in tumors can grow by sprouting from pre-existing vessels or by recruitment of rare, circulating bone marrow-derived endothelial progenitor cells (Avraamides et al., 2008). Tumor cells, macrophages and fibroblasts within tumors secrete factors, such as vascular endothelial growth factor (VEGF), that induce blood vessel growth in tumors (Adams and Alitalo, 2007; Schmid and Varner, 2007). Basic and clinical studies indicate that suppression of angiogenesis can inhibit tumor progression and metastasis (Folkman, 1971). Angiogenic protein array monitored both pro-and anti-angiogenic proteins show that 17 out of 24 proteins are pro-angiogenic factors. The majority of them (G-CSF, GMCSF, IGF-11, IL- $1 \alpha$, IL- $\beta$, IL-G, IL-9, TNF- $\alpha$, MCP1, eotaxin, bFGF, VEGF, leptin, and thrombopoietin) are involved in all tumor angiogenesis steps and most of these factors have pro-inflammatory effects that strengthen their proangiogenic effects and support tumor growth. Moreover, IL-6 has an anti-apoptotic effect on cancer cells by inhibition of p53 induced-apoptosis. On the other hand, FasL helps tumor cells to escape immune surveillance by inducing apoptosis of $\mathrm{T}$ cells (Banciu et al., 2006). New findings indicate that select integrins can modulate lymphangiogenesis and may thereby affect tumor metastasis (Avraamides et al., 2008). Angiogenesis is stimulated by tumor-associated macrophages. Circulating bone marrow-derived cells (monocytes) migrate into tumors in response to tumor secreted chemokines and differentiate into macrophages. Pro-angiogenic tumor macrophages release a number of potent proangiogenic cytokines, such as VEGFA, VEGFC, tumor necrosis factor alpha (TNF- $\alpha$ ), interleukin 8 (IL8) and basic fibroblast growth factor (bFGF, also known as FGF2) (Molina et al., 2005; Schmid and Varner 2007; Lin and Pollard, 2007) and express a broad array of extracellular matrix (ECM) degrading proteases, including urokinase type plasminogen activator (UPA, also known as PLAU), and the matrix metalloproteinases MMP2, MMP7, MMP9 and MMP12, and elastase (Schmid and Varner, 2007).

Glucorticoids (GC) exert a broad variety of activities on mammalian cells, including immunosupressive, antiinflammatory, apoptotic, necrotic and anti-angiogenic effects. In principle, all these effects, both at the genomic and non-genomic level, could play a role in the antitumor activity exerted by GC. The genomic mechanisms are induced by very low concentrations of GC. These mechanisms are determined by the interaction of GC with their cytosolic receptors (cGCR) followed by cGCR activation and translocation into the nucleus. Once in the nucleus, the GC/cGCR complexes modulate the activity of transcription factors, such as activator protein-1 (AP-1), nuclear factor $\mathrm{kB}(\mathrm{NF}-\mathrm{kB})$ and nuclear factor of activated $\mathrm{T}$ cells (NF-AT). This leads to regulation of the expression of genes for many immunoregulatory and inflammatory cytokines (TNF- $\alpha$, GM-CDF, IL-1a, 2, 6, 8, 11), for apoptotic 
proteins (members of the Bcl-2 family such as Bcl- $x_{s}$, Bad, Bax, Bid, Fasl), as well as pro-angiogenic proteins (like bFGF and VEGF) (Amsterdam et al., 2002; Schmidt et al., 2004; Smoak and Cidlowski, 2004). Higher dosages increase cGCR occupation, which intensifies the GC effects at the genomic level. If cGCR are saturated, GC can additionally induce non-genomic effects. Non-genomic actions involve three mechanisms: 1) cGCR-mediated inhibition of arachidonic acid release, 2) intercalation of GC molecules in cellular membranes, thus altering cationic transport through the plasma membrane and increasing proton leak out of the mitochondria, and 3) binding of GC to specific membrane-bound receptors (Buttgereit et al., 2004). The responses induced by GC non-genomic mechanisms include immunosuppressive and anti-inflammatory effects and necrosis induction.

Previously, we have shown that $10^{-9} \mathrm{M}$ of Betamethasone ( $\beta$-met) (minimal antiangiogenic concentration) mediated a considerable inhibition of neovascularization promoted by murine $\mathrm{A} / \mathrm{J} \mathrm{TA}_{3}$ tumor supernatant on the chorioallantoic membrane (CAM) of 12-day chick embryos (Lemus et al., 2001). On the other hand, the association of $\beta$-met with ketoprofen produced a synergistic effect, significantly decreasing tumor angiogenesis on CAM (Zúñiga et al., 2003). Moreover, inflammatory angiogenesis promoted by polyurethane sponge on mice, was strongly inhibited by low concentrations of $\beta$-met or sulindac, alone or combined (Illanes et al., 2002).

The purpose of this study was to investigate the in vivo $\beta$ met effects on a murine TA3-MTX-R tumor model, with a focus on tumor growth, angiogenesis and survival time.

\section{MATERIALS AND METHODS}

Eight-week-old, 25-g females A, J mice, clinically healthy, were obtained from our Central Animal Facility and kept under standard conditions, with 12-hour light, dark cycles and food and water provided ad libitum. Experiments were performed according to the national regulations and were approved by the local animal experimentation ethics committee. Twenty-six animals were used in this work. For tumor induction, all mice were inoculated intramuscularly (day 1 ) in the gluteal region with $0.2 \mathrm{ml}$ of ascites containing $1 \times 10^{6}$ multiresistant A, J mice $\mathrm{TA}_{3}-\mathrm{MTX}-\mathrm{R}$ tumor cells (Zipper et al., 1995; Gajardo et al., 2001; Plaza et al., 2008; Plaza et al.; 2009). 95\% viability of these tumor cells was determined by trypan blue exclusion counted in a Neubauer's chamber. Palpable and measurable tumors appeared 4-5 days after injection. These were measured daily and the volume estimated by the formula $\mathrm{V}=0.52 \mathrm{x} \mathrm{a}^{2} \mathrm{xb}$ where $\mathrm{a}=$ longest diameter, $\mathrm{b}=$ shortest diameter (O'Reilly et al., 1994). Two groups were considered: (A) control $n=6$, injected intraperitoneally (ip) with PBS and (B) experimental $\mathrm{n}=20$, inoculated ip with $10 \mu \mathrm{g}$ /animal of $\beta$-met, a dose known to inhibit angiogenesis (Illanes et al., 2002). On day 22 , the first death occurred in the control group. On that day, the rest of the control mice $(n=5)$ and 2 mice from $(B)$, were killed by continuous ether inhalation. Thus, tissue samples from lymphatic regional ganglia, lung, heart and spleen, as well as tumor and intestinal samples (as a control for Ki-67 effects), were isolated and fixed in $10 \%$ formaldehyde. A search for metastasis sites was performed, using a meso- microscopic study with standard Hematoxylin-eosin staining. To examine the effect of $\beta$-met on survival, the remaining 18 mice (B) were equally divided into B1 and B2 subgroups. In $\mathrm{B} 1(\mathrm{n}=8)$, the treatment with $\beta$-met was discontinued while in B2 $(n=10)$ was continued. In double blind experiments, three independent observers evaluated the total number of capillaries present in $0.081 \mathrm{~mm}^{2}$ tissue sections, at 400X. The tumor periphery and metastasis sites were used to avoid the central heterogeneity reported (central necrosis, fibrosis, etc.) (Folkman, 1971). Five histological slides per organ for each mouse were prepared, and counts in 4 fields in the periphery of the tumor and metastasis of every Arteta stained tissue section were performed. In order to assess blood vessel formation, 15 fields per group for every organ studied were counted. Arteta staining improves the visualization of blood vessels in a tissue.

Cell proliferation was studied by immunohistochemical detection of Ki-67 antigen. The polyclonal antibody (Novocastra, Cat\#NCL-Ki67-P) labels Ki-67 antigen in the granular components of the nucleolus during late G1, S, G2 and $M$ phases. Negative and Positive Controls were performed. (Scholzen and Gerdes, 2000). Immunohistochemical evaluation was made with a semiquantitative estimation of a field and observed by three observers in double blind technique.

Comparisons of blood vessel density and tumor volume between controls and the different experimental conditions were performed using Student's $t$ test for independent samples. Survival was calculated using Kaplan-Meier (STATA program).

\section{RESULTS}

\section{$\beta$-met inhibits the growth of a murine TA3-MTX-R tumor}

As indicated in Fig. 1, palpable and measurable tumors appeared 4 days after injection. Significant differences in volume could be detected starting day 8 after treatment when tumor volume in controls $(n=6)$ was $1594 \pm 76.55$ $\mathrm{mm}^{3}$, versus $854 \pm 29 \mathrm{~mm}^{3}$ in the experimental group $(\mathrm{n}=18)$ $(\mathrm{P}<0.001)$. On day 22 , tumor volume was $5425 \pm 282 \mathrm{~mm}^{3}$ in the control group versus $3856 \pm 122 \mathrm{~mm}^{3}$ in the experimental $(\mathrm{P}<0.001)$. When treatment for $\mathrm{B} 1$ group was discontinued, the tumor volume increased significantly when compared to the B2 group $(p<0,0001)$, and all animals of the B1 group died 48 days after injection while the B2 group the tumor volume decreased gradually during the experiment, showing stabilization between days 50 and 58 after treatment with an average tumor volume of $379 \pm 67 \mathrm{~mm}^{3}$. Later, tumor growth progressively reached $8125 \pm 87.6 \mathrm{~mm}^{3}$ on day 88 , and the remaining mice died.

Associated with the tumor growth rate control group (A), we observed an important and rapid progress of their clinical deterioration, characterized by detriment of the general state, loss of hair, increase in leg volume, inflammation, lameness with necrosis, distal hemorrhage of the posterior right extremity, and progressive decrease in food ingestion. All these signs were not found in the treated group (B), where we observed a minor general detriment, more reactivity and attentiveness to environmental stimuli, and improved mobility and appetite. 


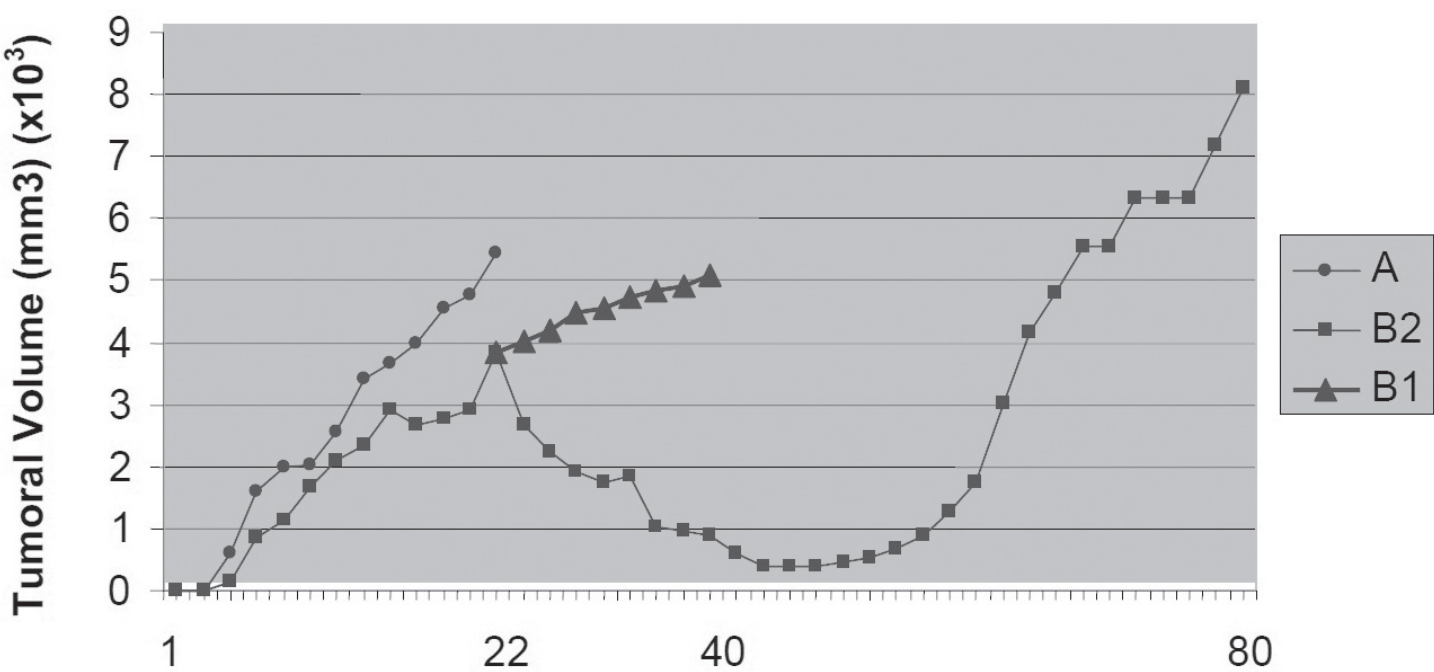

days

Figure 1: $\beta$-met inhibits the growth of a murine TA3-MTX-R tumor. Treatment started from day 4 . Significant differences were seen

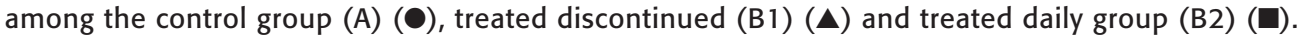

$\beta$-met decrease microvessel density in a murine organ with a TA3MTX-R tumor.

As summarized in Table I, a significant decrease in the number of vessels per area was detected in the $\beta$-met group versus the placebo group in every studied tissue. In group A (control), we detected an average of $8.6 \pm 1.0$ (mean \pm sem) vessels/area (v/ac) versus $4.0 \pm 0.6 \mathrm{v} / \mathrm{ac}$ in group B ( $\beta$-met) when we observed tumor slides.(Figure $3 \mathrm{~A}$ ) In regional lymph nodes, $4.4 \pm 0.6$ vessels in A versus $2.9 \pm 0.3$ vessels in $\mathrm{B}$, in lungs, $55.7 \pm 3.25$ in A versus $39.9 \pm 2.5$ in $\mathrm{B}$; in heart, $14.8 \pm 1.9$ in $\mathrm{A}$, versus $13 \pm 2.0$.

\section{$\beta$-met decreases cell proliferation in TA3-MTX-R tumors}

The immunohistochemical detection of Ki-67 showed a significant decrease in Group B when compared to Group A $(\mathrm{P}<0.001)$. Group B showed many zones with negative Ki-67 cells, while Group A showed major cell proliferation in the entire tumor. (Figure 3 B) The marker is brown and the staining interpretation was made in cells with a nuclear staining pattern.

\section{Table I}

$\beta$-met inhibits angiogenesis in a murine TA3-MTX-R tumor

\begin{tabular}{lcccc}
\hline Organ & $\mathrm{n}$ & $\begin{array}{c}\mathrm{PBS} \\
(\text { mean } \pm \text { sem })\end{array}$ & $\begin{array}{c}\beta \text {-met } \\
(\text { mean } \pm \text { sem })\end{array}$ & $\mathrm{P}$ \\
\hline Tumor & 15 & $8.6 \pm 1.0$ & $4.0 \pm 0.6$ & 0.0005 \\
Lymph nodes & 15 & $4.4 \pm 0.6$ & $2.9 \pm 0.3$ & $<0.05$ \\
Lung & 15 & $55.7 \pm 3.25$ & $39.9 \pm 2.5$ & 0.0006 \\
Heart & 15 & $14.8 \pm 1.9$ & $13.0 \pm 2.0$ & $0.5194^{*}$ \\
\hline
\end{tabular}

*: Not statistically significant

Blood vessels were examined in the Arteta stained organ sections of mice that died on day 22 and in the organs of mice remaining alive. Dates are expressed as number of vessels in $0.0081 \mathrm{~mm}^{2}$. $\beta$-met increases the survival of A/J mice bearing TA3-MTX-R tumors.

To examine the effect of $\beta$-met on mice survival, the animals were divided in two groups: (B1) $\beta$-met-treated discontinued and (B2) $\beta$-met-treated continued.

Figure 2 shows that in B1, the median survival was 32 days and in B2 the median was 63 days. Treatments (PBScontrol and $\beta$-met) were started 4-5 days after tumor injection and continued for 88 days. The day of death represents the number of days after the injection. Some $90 \%$ of PBS-treated died by day 22, while $\beta$-met-treated mice survived until day 88 .

\section{DISCUSSION}

The GCs exert a broad variety of effects on mammalian cells, including anti-inflammatory, immunosuppressive, antiangiogenic, apoptotic, and necrotic effects. These actions are mediated by genomic and non-genomic mechanisms. The present study provides insight into the mechanism of antitumor action of $\beta$-met. In fact, in the clinical setting, GCs have been used for their anti-inflammatory and anti-emetic effects. In addition, GC has been applied clinically in the treatment of hematological malignancies because it has efficient cytolytic activity on cells of lymphoid origin (Schiffelers et al., 2005). On the other hand, there are indications that GCs have inhibitory actions on solid tumor growth due to suppressive effects on tumor angiogenesis and inflammation (Folkman et al., 1983; Banciu et al., 2006) Preclinical studies on solid tumor growth inhibition indicate that GC-induced antitumor effects are obtained by using substantially higher doses than the minimal ones needed to achieve inhibition of inflammation. For example, to obtain antitumor effects in tumor-bearing mice, frequent and high doses of cortisone in the range of $500-700 \mathrm{mg} / \mathrm{kg}$ are needed (Folkman et al., 1983; Penhaligon and Camplejohn, 1985; Banciu et al., 2008). In these studies, some animals died due to opportunistic infections, indicating that severe systemic 


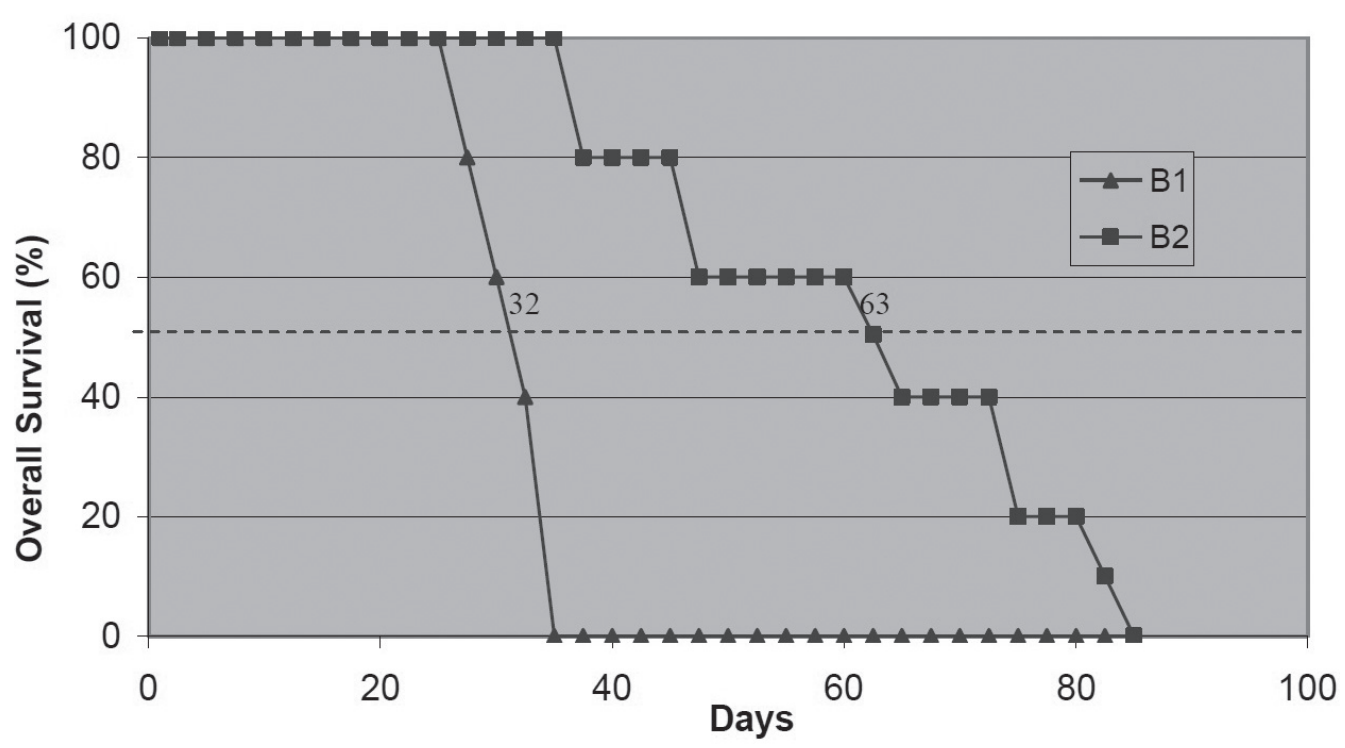

Figure 2: $\beta$-met increases the survival of $A / J$ mice bearing TA3-MTX-R tumors. The median duration of survival (indicated by the dotted lines) was 32 days in the group where $\beta$-met treatment was discontinued, as compared to 63 days in the group receiving continuous treatment $(p<0.05$, Kaplan-Meier Estimate of Survival).
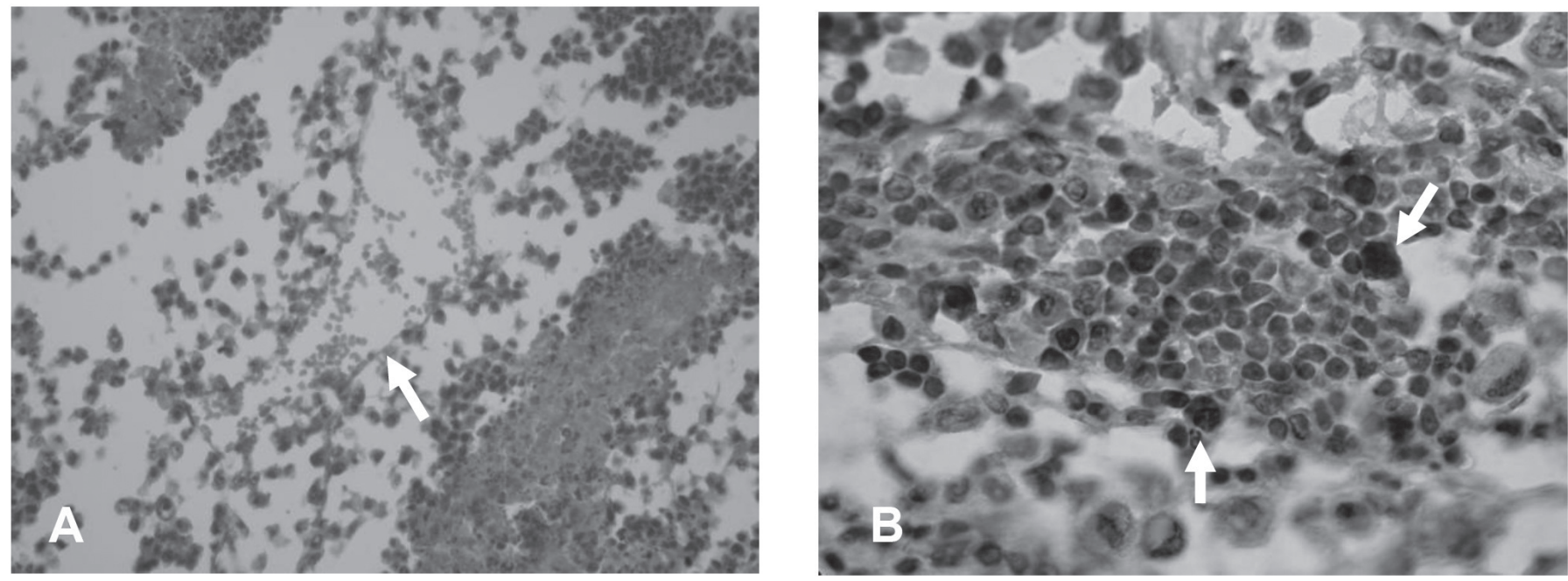

Figure 3: A: Arteta Staining in TA3-MTX-R tumor. The white arrow indicates a blood vessel. This staining was used for blood vessel counting (Arteta, 400x). B: Ki-67 immunodetection in TA3-MTX-R tumor. Ki-67 positive cells are marked in brown and indicated with a white arrow (IHC anti-Ki67, 1000x).

immune suppression can occur (Penhaligon and Camplejohn, 1985). On the other hand, GC regulate the production and activity of a broad variety of inflammatory and angiogenic proteins. These include enzymes responsible for the synthesis of key mediators of inflammation, for the degradation of basal membranes and for the reorganization of extracellular matrix of blood vessels; peptide growth factors; mediators of inflammatory reactions; and cell adhesion molecules (Yang et al., 2002; Lubet et al., 2004; Banciu et al., 2008). These actions are exerted by GC at genomic and nongenomic levels. Additional contributing factors could be the inhibition of phospholipase $\mathrm{A}_{2}$ transcription produced by stimulus in the production of proteins, such as Lipocortin 1 (Buttgereit, 1998). This decrease in phospholipase $A_{2}$ levels produces an inhibition in the cascade of arachidonic acid, thus diminishing the production of some well-known proinflammatory and proangiogenic mediators, such as prostaglandins, tromboxans and leucotriens. Prostaglandins stimulate directly and indirectly the transcription of numerous important proangiogenic factors (Höper, 1997; Cheng, 1998). In fact, one of the main inhibitory actions of GC on tumor inflammation is the downregulation of expression of genes encoding for enzymes involved in synthesis of prostaglandin $\mathrm{E}_{2}\left(\mathrm{PGE}_{2}\right)$, such as cytosolic phospholipase $\mathrm{A}_{2}\left(\mathrm{cPLA}_{2}\right)$ and cyclooxygenase 2 (COX-2) (Croxtall et al., 2002; Farooqui et al., 2007). Inhibition of the production of $\mathrm{PGE}_{2}$, a key mediator of inflammation, leads to a supplementary reduction of growth factors, cell adhesion molecules, and metalloproteinases involved in different steps of tumor angiogenesis (Vassiliou et al., 2004). Remarkably, GC appears to have no reducing effects on the levels of most of the antiangiogenic and anti-inflammatory proteins, allowing these 
proteins to mediate downregulation of genes encoding for pro-angiogenic factors (VEGF, bFGF, $\mathrm{MMP}_{\mathrm{s}}$ ) (Reichenstein et al., 2004; Banciu et al., 2006, 2008). These effects of GC on the production of angiogenic/inflammatory factors in tumors can cause a shift in the balance between pro- and antiangiogenic factors in favor of inhibition of inflammationassociated angiogenesis, thus diminishing tumor growth. Our in vivo studies indicate that $\beta$-met inhibits tumor growth (Figure 1) by virtue of its capacity to interfere with angiogenesis (Table I). This inhibition of tumor angiogenesis may be due to a reduction of intratumor levels of proangiogenic factors, as well as to a direct inhibition of endothelial and tumoral cell proliferation.

Our results show that, the smaller tumoral volume in group B1 (Figure 1), could be related with the $\beta$-met antiangiogenic and proapoptotic properties.

Interestingly, starting on day 57 post-inoculation, tumor size in group B2 began a rapid progression until the animals died (Figure 1). Perhaps this difference between the two B groups can be explained by tumor drug resistance given by the emergence of more proangiogenic and aggressive clones within the tumoral masses. Hypoxia, proangiogenic through different mechanisms (Forsythe et al., 1996; Brown et al., 1997; Carmeliet, 2000), is produced by rapid tumor growth associated with a poor vascularized environment (Griffioen, 2000). This information refutes several studies proposing that an acceptable antiangiogenic therapy for cancer should not elicit medium term resistance (O'Reilly et al., 1994; 1997). It has also been demonstrated that hypoxia in tumors tends to select for a more malignant phenotype, increases mutation rates, increases expression of genes associated with angiogenesis and tumor invasion, and is associated with a more metastatic phenotype of human cancers. Therefore, hypoxia has a key negative role in tumor prognosis, both because it causes resistance to standard therapies and because it promotes a more malignant phenotype (Brown and Wilson, 2004)

Capillary counting in Arteta stained sections, as an indicator of angiogenesis, shows a significant decrease in the number of vessels, thus corroborating the effect of $\beta$-met in other models, and correlates with the tumor size evolution (A vs. B1, Figure 1) in our model. Finally, the secondary increase of the tumor aggressiveness in our model resulted in the increase of the tumor size and the number of vessels towards the end of the experience in group B2 (Figure 1). For this reason, this treatment could complement other experimental chemotherapies against multiresistant tumors. As well, it could be used to decrease the tumor size before surgery (in tumors like the one used in this experiment, TA3MTX-R), or associated with other drugs. As an important perspective, we will experimentally combine these strategies with those recently described by us with regard to Trypanosoma cruzi calreticulin important antiangiogenic antitumor effects. Since the molecular targets of these strategies are most likely different, additive or synergic effects are envisaged. As an important perspective, we will soon experimentally combine these strategies with those recently described by us with regard to Trypanosoma cruzi calreticulin important antiangiogenic - antitumor effects (López et al., submitted). Since the molecular targets of these strategies are most likely different, additive or synergic effects are envisaged.

\section{ACKNOWLEDGMENTS}

The authors thank the reviewers for their valuable comments on the manuscript. This paper is part of the thesis for the Master Degree in Medical Sciences (Morphology) by Osvaldo Garrido.

\section{REFERENCES}

ADAMS RH, ALITALO K (2007) Molecular regulation of angiogenesis and lymphangiogenesis. Nature Rev Mol Cell Biol 8: 464-478.

AMSTERDAM A, TAJIMA K, SASSON R (2002) Cell-specific regulation of apoptosis by Glucocorticoids: implications to their anti-inflammatory action. Biochem Pharmacol 64 (5-6): 843-850.

ARANDA E, OWEN G (2009) A semi-quantitative assay to screen for angiogenic compounds and compounds with angiogenic potential using EA.hy926 endothelial cell line. Biol Res 42: 263-389.

AVRAAMIDES CJ, GARMY-SUSINI B, VARNER JA (2008) Integrins in angiogenesis and lymphangiogenesis. Nat Rev Cancer 8: 604-617.

BANCIU M, SCHIFFELERS R, FENS M, METSELAAR J, STORM G (2006) Anti-angiogenic effects of liposomal prednisolone phosphate on B16 melanoma in mice. J Control Releases 113 (1): 1-8.

BANCIU M, SCHIFFELERS R, METSELAAR J, STORM, G (2008) Utility of Targeted Glucorticoids in Cancer Therapy. J Liposome Res 18: 47-57.

BOUCK N, STELLMACH V, HSU SC (1996) How tumors become angiogenic. Adv Cancer Res 69: 135-174.

BROWN LF, DETMAR M, CLAFFEY K, NAGY JA, FENG D, DVORAK AM, DVORAK HF (1997) Vascular permeability factor/VEGF: a multifunctional angiogenic cytokine. EXS 79: 233-269.

BROWN JM, WILSON WR.(2004) Exploiting tumour hypoxia in cancer treatment. Nat Rev Cancer 4: 437-447.

BUSCHMAN I, SCHAPER W (2000) The pathophysiology of the collateral circulation. J Pathol 190: 338-342.

BUTTGEREIT F, WEHLING M, BURMESTER GR (1998) A new hypothesis of modular glucocorticoid actions. Arthritis \& Rheumatism 41: 761-767.

BUTTGEREIT F, STRAUB RH, WEHLING M, BURMESTER GR (2004) Glucocorticoids in the treatment of rheumatic diseases: an update on the mechanisms of action. Arthritis Rheum 50: 3408-3417.

CARMELIET P (2000) Mechanism of angiogenesis and arteriogenesis. Nature Med 6: 389-395.

CARMELIET P (2005) Angiogenesis in life, disease and medicine. Nature 42: $932-936$.

CHENG T, CAO W, WEN R, STEINBERG R, LAVAIN M (1998) Prostaglandin E2 induces VEGF and FGFb mRNA expression in cultured rat Muller cells. Invest Ophthalmol Vis 39: 581-591.

CROXTALL JD, VAN HAL PT, CHOUDHURY Q, GILROY DW, FLOWER RJ (2002) Different glucocorticoids vary in their genomic and no genomic mechanism of action in A549 cells. Br J Pharmacol 135: 511519.

FAROOQUI M, GENG ZH, STEPHENSON EJ, YEE D, GUPTA K (2006) Naloxone acts as an antagonist of estrogen receptor in MCF7 cancer cells. Mol Cancer Ther 5: 611-620.

FERREIRA V, MOLINA CM, SCHWAEBLE W, LEMUS D, FERREIRA A (2005) Does Trypanosoma cruzi calreticulin modulate the complement system and angiogenesis? Trends Parasitol 21(4): 169-174.

FOLKMAN J (1971) Tumor angiogenesis: Therapeutic implications. NEJM 285: 1182-1186.

FOLKMAN J, LANGER R, LINHARDT RJ, HAUDENSCHILD C, TAYLOR $S$ (1983) Angiogenesis inhibition and tumor regression caused by heparin or a heparin fragment in the presence of cortisone. Science, 221: 779 .

FOLKMAN J (2000) In cancer medicine (eds. Holland, J.F. et. Al.) 132-152 (Decker, Ontario, Canada).

FORSYTHE JA, JIANG BH, IYER NV, AGANI F, LEUNG SW, KOOS RD, SEMENZA GL (1996) Activation of VEGF gene transcription by Hipoxia-Inducible factor 1. Mol Cell Biol 16: 4604-4613.

GAJARDO P, CORDANO G, PAVANI M, MUÑOZ S, RIVERA E, MEDINA J, GUERRERO A, FERREIRA J (2001) La inhibición de la respiración mitocondrial por el éster 2,6-Dihidroxi-4Carboxifenoxiacetato de bis isopropilo (CARFENISTOP) y su papel como restaurador de la sensibilidad a fármacos antineoplásicos en el carcinoma multiresistente TA3-MTX-R transplantable de ratón. Rev Chi Cancerología y Hematología 11: 162-174. 
GRIFFIOEN A, MOLEMA G (2000) Angiogenesis: Potentials of pharmacologic intervention in the treatment of cancer cardiovascular diseases and chronic inflammation. Pharmac Rev 52 (2): 237-267.

HANAHAN D, WEINBERG R (2000) The hallmarks of Cancer. Cell 100: 57-100.

HÖPER MM, VOELKEL NF, BATES TO, ALLARD JD, HORAN M, SHEPHERD D, TUDER RM (1997) Prostanglandins induce VEGF in a human monocytic cell and rat lung via camp. Am J Respir Cell Mol Biol 17: 748-756.

ILLANES J, DABANCENS A, ACUÑA O, FUENZALIDA M, GUERRERO A, LOPEZ C, LEMUS D (2002) Effect of betamethasone, sulindac and quinacrine drugs on the inflammatory neoangiogenesis response induced by polyurethane sponge implanted in mouse. Biol Res 35: 339-345.

KOLENSNIK RN, KRANKE M (1998) Reg. of ceramide production and apoptosis. Ann Rev Physiol 60: 643-665.

KROEMER G, DALLAPORTA B, AND RESCHE-RIGON M (1998) The mitocondrial death/Life regulations in apoptosis and necrosis. Ann Rev Physiol 60: 619-642.

LEMUS D, DABANCENS A, ILLANES J, FUENZALIDA M, GUERRERO A, LÓPEZ C (2001) Antiangiogenic effect of betametasona on the chick CAM stimulated by TA3 tumor supernatant. Biol Res 34: 227236.

LIN EY, POLLARD JW (2007) Tumor-associated macrophages press the angiogenic switch in breast cancer. Cancer Res 67: 5064-5066.

LIOTTA LA, KOHN EC (2001) The microenvironment of the tumor - host interface. Nature 411: 375-379.

LÓPEZ N, VALCK C, RAMÍREZ G, RODRÍGUEZ M, RIBEIRO C, ORELLANA J, MALDONADO I, ALBINI A, ANACONA D, LEMUS D, AGUILAR L, SCHWAEBLE W, FERREIRA A (2010). Trypanosoma cruzi calreticulin mediates key antiangiogenic effects of non endothelial cells. PLos Neglected Tropical Diseases. (In Press).

LUBET R, TAO L, WANG W, KRAMER P, PERREIRA M. (2004) Effects of budesonide on overall 5-methylcytosine levels and specific methylation and messenger RNA expression of the insuline-like growth factor II gene in mouse lung tumors. Chest 125: $157 \mathrm{~S}$.

MALONNE H, LANGER I, KISS R, ATASSI G (1999) Mechanism of tumor angiogenesis and therapeutic implications: angiogenesis inhibitor. Clin Exp Met 17: 1-41.

MOLINA MC, FERREIRA V, VALCK C, AGUILAR L, ORELLANA J, ROJAS A, RAMIREZ G, BILLETTA R, SCHWAEBLE W, LEMUS D, FERREIRA A. (2005). An in vivo role for Trypanosoma cruzi calreticulin in antiangiogenesis. Mol. Biochem. Parasitol. 140: 133140 .

O’REILLY MS, HOLMGREN L, SHING Y, CHEN C, ROSENTHAL RA CAO Y, MOSES M, LANE WS, SAGE EH, FOLKMAN L (1994) Angiostatin: a circulating endothelial cell inhibitor that suppresses angiogenesis and tumor growth. En: Cold Springs Harbor Symposia on quantitative Biology 59: 471-482.

O’REILLY MS, BOEHM T, SHING Y, FUKAI N, VASIOS G, LANE WS, FLYNN E, BIRKHEAD JR, OLSEN BR, FOLKMAN J (1997)
Endostatin: an endogenous inhibitor of angiogenesis and tumor growth. Cell 88: 277-285.

PENHALIGON M, CAMPLEJOHN RS (1985) Combination heparin plus cortisone treatment of two transplanted tumors in $\mathrm{C} 3 \mathrm{H} / \mathrm{He}$ mice. J Natl Cancer Inst. 74: 689.

PIKE SE, YAO L, SETSUDA J, et al. (1999). Calreticulin and calreticulin fragments are endotelial cell inhibitors that suppress tumor growth. Blood 94: 2461-2468.

PLAZA C, PAVANI M, ARAYA-MATURANA R, PEZOA J, MAYA JD, MORELLO A, BECKER MI, DE IOANNES A, FERREIRA J (2009) Chemosensitizing effect of nordihydroguaiaretic acid and its tetraacetylated derivative on parental and multiresistant TA3 mouse mammary adenocarcinoma cells. In Vivo Nov-Dec; 23(6): 959-967.

PLAZA C, PAVANI M, FAUNDEZ M, MAYA JD, MORELLO A, BECKER MI, DE IOANNES A, CUMSILLE MA, FERREIRA J (2008) Inhibitory effect of nordihydroguaiaretic acid and its tetra-acetylated derivative on respiration and growth of adenocarcinoma TA3 and its multiresistant variant TA3MTX-R. In Vivo May-Jun; 22(3): 353-361.

REICHENSTEIN M, REICH R, LEHOUX JG, HANUKOGLU I. (2004) ACTH induces TIMP-1 expression and inhibits collagenase in adrenal cortex cells. Mol Cell Endocrinol 215: 109-114.

SCHIFFELERS RM, METSELAAR JM, FENS MH, JANSSEN AP, MOLEMA G, STORM G. (2005) Liposome-encapsulated prednisolone phosphate inhibits growth of established tumors in mice. Neoplasia 7: 118.

SCHMID MC, VARNER JA (2007) Myeloid cell trafficking and tumor angiogenesis. Cancer Lett 250: 1-8.

SCHMIDT S, RAINER J, PIONER C, PRESUL E, RIML S, KOFLER R (2004) Glucocorticoid-induced apoptosis and glucocorticoid resistance: molecular mechanisms and clinical relevance. Cell Death Differ (Suppl 1): 45-55.

SCHOLZEN T, GERDES J (2000) The Ki-67 Protein: From the Known and the Unknown. J Cell Physiol 182: 311-322.

SMOAK KA, CIDLOWSKI JA (2004) Mechanisms of glucocorticoids receptor signaling during inflammation. Mech Ageing Dev 125: 697706.

STRAUSS L, FUENZALIDA M, ILLANES J, DABANCENS A, DIAZ A LEMUS D, GUERRERO A (2002) Effect of sulfated b-cyclodextrin, a water soluble cycloamylose, on the promotion and/or inhibition of angiogenesis. Pathol Oncol Res 8: 47-53.

VASSILIOU E, SHARMA V, JING H, SHEIBANIE F, GANEA D. (2004) Prostaglandin E2 promotes the survival of bone marrow-derived dendritic cells. J Immunol 173: 6955-6964.

YANG EV, BANE CM, MACCALLUM RC, KIECOLT-GLASER JK, MALARKEY WB, GLASER R (2002) Stress-related modulation of matrix metalloproteinase expression. J Neuroimmunol 133: 144.

ZIPPER J, DABANCENS A, GUERRERO A, TRUJILLO V (1995) Quinacrine Revised. Human Reprod Update 1 (4): 324-342.

ZUÑIGA J, FUENZALIDA M, GUERRERO A, DIAZ E, LEMUS D (2003) Effects of steroidal and non steroidal drugs on the revascularization response induced by tumoral TA3 supernatant on CAM from chick embryo. Biol Res 36: 233-240 